\title{
Molecular profiling currently offers no more than tumour morphology and basic immunohistochemistry
}

\author{
Britta Weigelt ${ }^{1}$ and Jorge S Reis-Filho ${ }^{2 *}$
}

\begin{abstract}
Introduction
The management of breast cancer patients is still guided based on a constellation of clinicopathological features, including prognostic markers derived from careful histopathological analysis of tumours, namely tumour size, histological grade, presence of lymph node metastasis and vascular invasion [1-3]. Despite the huge amount of resources allocated to translational research endeavours, only three predictive markers are utilised to define the therapy of breast cancer patients: oestrogen receptor (ER) and progesterone receptor (PR), the predictive markers of response to endocrine therapy, and human epidermal growth factor receptor 2 (HER2), the molecular target of trastuzumab and lapatinib. These parameters are then used in conjunction either in the form of guidelines (for example, St Gallen's consensus criteria) or included in multivariable algorithms (for example, Adjuvant!Online) for clinical decision making [1-3]. Albeit seemingly simplistic, this approach has been shown to be clinically relevant, given that predictions made with Adjuvant!Online do correlate with the actual outcome of breast cancer patients [4], and, most importantly, the use of this framework to define the systemic therapy of breast cancer patients has contributed to the steady decline in the mortality of breast cancer patients [5]. Although effective, this approach is not sufficient for the potential of individualised therapy to be realised.

The promise of high throughput technologies, and in particular of gene expression profiling with microarrays, has been of apocalyptic dimensions [6-9]. The objectivity of the methodology coupled with the elaborate, if not mind boggling [10], bioinformatic approaches to answer clinically relevant questions have led some of the
\end{abstract}

\footnotetext{
*Correspondence: Jorge.Reis-Filho@icr.ac.uk

${ }^{2}$ Molecular Pathology Laboratory, The Breakthrough Breast Cancer Research

Centre, Institute of Cancer Research, London, SW3 6JB, UK

Full list of author information is available at the end of the article
}

proponents of this technology to compare histopathology with some rituals practiced by ancient tribes [7], and some experts in the field predicted back in 2000 that microarrays would make conventional diagnostic techniques obsolete [6].

Microarrays and their derivatives have undoubtedly contributed to our understanding of breast cancer (for reviews, see $[1,2])$. They have provided direct evidence to demonstrate that breast cancer is a heterogeneous disease at the molecular level [11], that ER-positive and -negative diseases are fundamentally different [11-14], that molecular subtypes of breast cancer do exist $[11,15-18]$, and that some special histological types of breast cancer are distinct entities at the molecular level [19-22]. Furthermore, they have led to the development of a molecular taxonomy that is currently being tested in clinical trials [16], and of prognostic 'gene signatures', some of which have already been approved by the US Food and Drug Administration [1,2,13,23].

\section{Molecular taxonomy}

From a conceptual standpoint, the development of a molecular taxonomy [11,15-18] for breast cancer has reshaped the way breast cancer is perceived. According to this classification, breast cancers can be subdivided into luminal tumours, which are ER-positive, express ERrelated genes and are reported to be subclassified into A and $\mathrm{B}$ according to the expression level of proliferationrelated genes $[1,2,15,16,24]$; HER2 tumours, which express HER2 and genes related to the HER2 amplicon; normal breast-like cancers, which are still poorly understood and are reported to express genes usually found in normal breast samples; and basal-like cancers, which largely lack expression of ER, PR and HER2, and express genes usually found in basal/myoepithelial cells of the breast $[1,2,11,15-18,24]$. The terms luminal A, luminal B, normal breast-like, basal-like and HER2 have become part of our lexicon. The approach pioneered by the Stanford group, however, has some important limitations. First, our recent re-analysis of the methods for the identification of the molecular subtypes of breast cancer 
(that is, single sample predictors) demonstrated that only basal-like cancers can be reliably identified [25]; the classification of samples into the other molecular subtypes is dependent on the methods used for the classification of the samples and the agreement rates between different methods is modest [25,26]. In fact, even when the authors of the molecular taxonomy themselves classified the same cohort of breast cancer patients (that is, NKI-295 [23]) using two different methods $[27,28]$, one by Sorlie and colleagues [17,27] and the other by $\mathrm{Hu}$ and colleagues $[15,28]$, the agreement was only moderate (Kappa scores $=0.527$ (95\% confidence interval 0.456 to 0.597$)$ ). Second, there are several lines of evidence to suggest that normal breast-like cancers may constitute an artefact of gene expression profiling (that is, samples with a disproportionately high content of normal breast epithelial cells and stromal cells) [16,25]. Third, given that the subdivision of luminal tumours into $\mathrm{A}$ and $\mathrm{B}$ is driven by the levels of expression of proliferationrelated genes and that several studies have demonstrated that proliferation in ER-positive cancers is a continuum rather than a bi-modal distribution, this subclassification of luminal cancers is likely to be arbitrary $[1,2,12,14,16$, 25,29]. Fourth, the HER2 molecular subtype neither comprises all cases classified as HER2-positive with clinically validated methods (that is, immunohistochemical analysis and chromogenic/fluorescence in situ hybridisation) and not all HER2-positive cancers by clinical methods are classified as HER2 subtype by microarrays $[16,25,30]$. Therefore, for the microarray-based molecular taxonomy of breast cancer to be incorporated into clinical practice, standardisation of the definitions and the methodologies for the identification of the molecular subtypes and prospective clinical trials to validate the contribution of these five molecular subtypes in addition to the current clinicopathological parameters for prognosis prediction of breast cancer patients are required, and this is yet to be achieved.

\section{Prognostic gene signatures}

The development of microarray-based prognostic gene signatures was heralded as a major breakthrough for the management of breast cancer patients $[1,2,8,9,13,31-33]$. It was thought then that these signatures would provide a more objective assessment of the risk of relapse of breast cancer patients and would be more reproducible than the methods currently used $[1,2,8,9,33]$. The first prognostic gene signatures (that is, the 70-gene signature also known as Mammaprint ${ }^{\bullet}$ [13], and the 76-gene signature [31]) were developed to be applied to all breast cancer patients. Their performance in the training and validation datasets demonstrated objectively that the prognostic information provided by these signatures is indeed independent of the information provided by tumour size, presence of lymph node metastasis and histological grade [1,2,32]. Subsequent to these initial stories of success, several groups developed their own prognostic signatures either employing bottom-up or top-down approaches (for reviews, see $[1,2])$. In addition, independent groups developed microarray signatures to capture the information provided by histological grade $[34,35]$.

Following the initial enthusiasm with microarray-based prognostic gene signatures, re-analyses of the initial studies on cancer prognosis with microarrays have revealed that the overlap between gene signatures was negligible; that these first generation signatures were not stable in terms of their gene composition [36,37]; and that these gene signatures were time dependent (that is, their prognostic power is substantially reduced from 5 to 10 years of follow-up) [1,2,36-38]. These observations have led to a wave of (over)scepticism, with an expert in the field of biomarker discovery and validation stating that '.. on close scrutiny, in five of the seven largest studies on cancer prognosis, this technology performs no better than flipping a coin. The other two studies barely beat horoscopes" [39]. Fortunately, with the greater availability of microarray datasets in public repositories, meta-analyses performed by independent groups revealed that different gene signatures identify similar groups of patients as of poor outcome; that the assignment of cases as of poor outcome is based on the expression of proliferation-related genes; that these first generation signatures only have discriminatory power in ER-positive disease; and that proliferation is perhaps the strongest determinant of outcome in ER-positive disease $[12,14,28,40]$.

In parallel with the development of microarray-based gene signatures, a 21-gene signature based on quantitative real time RT-PCR was developed through a reanalysis of microarray datasets and a review of the literature $[41,42]$. This signature, named OncotypeDX ${ }^{\mathrm{TM}}$ (Genomic Health, Redwood, CA, USA) was developed and validated through a retrospective analysis of formalin-fixed, paraffin-embedded material from the prospective clinical trials B-20 and B-14 [41,42] (for reviews, see $[43,44])$. OncotypeDx ${ }^{\mathrm{TM}}$ has been shown to be prognostic in ER-positive tumours, but also identifies those patients who are likely to benefit most from chemotherapy [41-44]. Therefore, it can be used to determine which patients should receive endocrine therapy or a combination of endocrine plus chemotherapy. This test is only offered for central analysis in the Genomic Health laboratories and has been shown to be robust, so much so that it has been recommended for the management of breast cancer patients by the American Society of Clinical Oncology (ASCO) guidelines on the use of tumour markers in breast cancer, and in the National Comprehensive Cancer Network (NCCN) guidelines for 
breast cancer treatment, as a predictor of recurrence for ER-positive, lymph node-negative breast cancer patients. Despite the important contribution of OncotypeDx ${ }^{\mathrm{TM}}$ for the management of breast cancer patients, it should be noted that this test is meant to be used in conjunction with the clinicopathological prognostic factors [2,41-44]. Furthermore, there is evidence to suggest that the prognostic power of Oncotype $\mathrm{Dx}^{\mathrm{TM}}$, in a way akin to the other first generation signatures, largely if not exclusively stems from the quantitative analysis of the levels of expression of proliferation-related genes $[1,2,14]$.

Despite the controversies above, the question that remains germane is whether molecular profiling offers more than the information provided by clinicopathological parameters and a handful of immunohistochemical markers. This was in part addressed by Dunkler and colleagues [45], who re-analysed the data from the cohort employed to validate the 70-gene signature and demonstrated that the contribution of this signature to the prognostication of breast cancer patients above and beyond that offered by the clinicopathological parameters was minimal. Furthermore, a recent comparison of the prognostic information provided by Oncotype $\mathrm{Dx}^{\mathrm{TM}}$ or four immunohistochemical markers (that is, ER, PR, HER2 and Ki67 - a proliferation marker) semi-quantitatively assessed in the material from the ATAC (Arimidex, Tamoxifen, Alone or in Combination) prospective trial demonstrated that these four markers would at least be equivalent to Oncotype $\mathrm{Dx}^{\mathrm{TM}}[46]$.

\section{Conclusion}

Taken together, it would be fair to say that, currently, molecular profiling does provide additional prognostic and to some extent predictive information to the current clinicopathological features and immunohistochemical markers routinely used. However, this information benefits a limited number of patients, is restricted to patients with ER-positive cancers, and seems only to constitute a reproducible and quantitative analysis of tumour cell proliferation. Therefore, pathologists should strive for developing robust and reproducible methods for the assessment of proliferation (for example, a standardised Ki67 immunohistochemical protocol and scoring system). Although the enthusiasm with microarrays has waned, this technology has provided an incremental step towards the individualisation of therapy for breast cancer patients. It is probable that this goal will be achieved through the integration of different layers of high-throughout data (that is, transcriptomics, proteomics, functional genomics). Furthermore, the development of massively parallel sequencing approaches $[47,48]$ and their application to the study of breast cancer is likely to provide information that will constitute another quantum leap in the way we perceive this complex disease, and help develop more accurate prognostic and predictive tests to each subgroup/subtype of breast cancers.

\section{Abbreviations}

$E R=$ oestrogen receptor; HER2 = human epidermal growth factor receptor $2 ;$ $P R=$ progesterone receptor.

\section{Competing interests}

The authors declare that they have no competing interests.

\section{Acknowledgements}

Britta Weigelt is funded by a CR-UK fellowship. Jorge Reis-Filho is funded in part by Breakthrough Breast Cancer.

This article has been published as part of Breast Cancer Research Volume 12 Supplement 4, 2010: Controversies in Breast Cancer 2010. The full contents of the supplement are available online at http://breast-cancer-research.com/ supplements/12/S4

\section{Author details}

'Signal Transduction Laboratory, Cancer Research UK London Research Institute, 44 Lincoln's Inn Fields, London, WC2A 3LY, UK. ²Molecular Pathology Laboratory, The Breakthrough Breast Cancer Research Centre, Institute of Cancer Research, London, SW3 6JB, UK.

\section{Published: 20 December 2010}

\section{References}

1. Sotiriou C, Pusztai L: Gene-expression signatures in breast cancer. N Eng/ J Med 2009, 360:790-800.

2. Weigelt B, Baehner FL, Reis-Filho JS: The contribution of gene expression profiling to breast cancer classification, prognostication and prediction: a retrospective of the last decade. J Pathol 2010, 220:263-280.

3. Correa Geyer F, Reis-Filho JS: Microarray-based gene expression profiling as a clinical tool for breast cancer management: are we there yet? Int I Surg Pathol 2009, 17:285-302.

4. Mook S, Schmidt MK, Rutgers EJ, van de Velde AO, Visser O, Rutgers SM, Armstrong N, van't Veer $\mathrm{L}$, Ravdin PM: Calibration and discriminatory accuracy of prognosis calculation for breast cancer with the online Adjuvant! program: a hospital-based retrospective cohort study. Lancet Oncol 2009, 10:1070-1076.

5. Autier P, Boniol M, LaVecchia C, Vatten L, Gavin A, Hery C, Heanue M: Disparities in breast cancer mortality trends between 30 European countries: retrospective trend analysis of WHO mortality database. BMJ 2010, 341:c3620.

6. Aparicio SA, Caldas C, Ponder B: Does massively parallel transcriptome analysis signify the end of cancer histopathology as we know it? Genome Biol 2000, 1:REVIEWS1021.

7. He YD, Friend SH: Microarrays - the 21st century divining rod? Nat Med 2001, 7:658-659.

8. van't Veer $\mathrm{L}$, Bernards R: Enabling personalized cancer medicine through analysis of gene-expression patterns. Nature 2008, 452:564-570.

9. van't Veer $L$, Paik S, Hayes DF: Gene expression profiling of breast cancer: a new tumor marker. J Clin Oncol 2005, 23:1631-1635.

10. Brenton JD, Caldas C: Predictive cancer genomics - what do we need? Lancet 2003, 362:340-341.

11. Perou CM, Sorlie T, Eisen MB, van de Rijn M, Jeffrey SS, Rees CA, Pollack JR, Ross DT, Johnsen H, Akslen LA, Fluge O, Pergamenschikov A, Williams C, Zhu $S X$, Lonning PE, Borresen-Dale AL, Brown PO, Botstein D: Molecular portraits of human breast tumours. Nature 2000, 406:747-752.

12. Desmedt C, Haibe-Kains B, Wirapati P, Buyse M, Larsimont D, Bontempi G, Delorenzi M, Piccart M, Sotiriou C: Biological processes associated with breast cancer clinical outcome depend on the molecular subtypes. Clin Cancer Res 2008, 14:5158-5165.

13. van't Veer $L$, Dai $H$, van de Vijver MJ, He YD, Hart AA, Mao M, Peterse HL, van der Kooy K, Marton MJ, Witteveen AT, Schreiber GJ, Kerkhoven RM, Roberts C, Linsley PS, Bernards R, Friend SH: Gene expression profiling predicts clinical outcome of breast cancer. Nature 2002, 415:530-536.

14. Wirapati P, Sotiriou C, Kunkel S, Farmer P, Pradervand S, Haibe-Kains B, 
Desmedt C, Ignatiadis M, Sengstag T, Schutz F, Goldstein DR, Piccart M, Delorenzi M: Meta-analysis of gene expression profiles in breast cancer: toward a unified understanding of breast cancer subtyping and prognosis signatures. Breast Cancer Res 2008, 10:R65.

15. Hu Z, Fan C, Oh DS, Marron JS, He X, Qaqish BF, Livasy C, Carey LA, Reynolds E, Dressler L, Nobel A, Parker J, Ewend MG, Sawyer LR, Wu J, Liu Y, Nanda R, Tretiakova M, Ruiz Orrico A, Dreher D, Palazzo JP, Perreard L, Nelson E, Mone M, Hansen H, Mullins M, Quackenbush JF, Ellis MJ, Olopade OI, Bernard PS, Perou CM: The molecular portraits of breast tumors are conserved across microarray platforms. BMC Genomics 2006, 7:96.

16. Parker JS, Mullins M, Cheang MC, Leung S, Voduc D, Vickery T, Davies $S$, Fauron C, He X, Hu Z, Quackenbush JF, Stijleman IJ, Palazzo J, Marron JS, Nobel AB, Mardis E, Nielsen TO, Ellis MJ, Perou CM, Bernard PS: Supervised risk predictor of breast cancer based on intrinsic subtypes. J Clin Oncol 2009, 27:1160-1167.

17. Sorlie T, Perou CM, Tibshirani R, Aas T, Geisler S, Johnsen H, Hastie T, Eisen MB, van de Rijn M, Jeffrey SS, Thorsen T, Quist H, Matese JC, Brown PO, Botstein D, Eystein Lonning P, Borresen-Dale AL: Gene expression patterns of breast carcinomas distinguish tumor subclasses with clinical implications. Proc Natl Acad Sci U S A 2001, 98:10869-10874.

18. Sorlie T, Tibshirani R, Parker J, Hastie T, Marron JS, Nobel A, Deng S, Johnsen H, Pesich R, Geisler S, Demeter J, Perou CM, Lonning PE, Brown PO, BorresenDale AL, Botstein D: Repeated observation of breast tumor subtypes in independent gene expression data sets. Proc Natl Acad Sci U S A 2003, 100:8418-8423.

19. Weigelt B, Horlings HM, Kreike B, Hayes MM, Hauptmann M, Wessels LF, de Jong D, Van de Vijver MJ, Van't Veer LJ, Peterse JL: Refinement of breast cancer classification by molecular characterization of histological special types. J Pathol 2008, 216:141-150

20. Lopez-Garcia MA, Geyer FC, Natrajan R, Kreike B, Mackay A, Grigoriadis A, Reis-Filho JS, Weigelt B: Transcriptomic analysis of tubular carcinomas of the breast reveals similarities and differences with molecular subtypematched ductal and lobular carcinomas. J Pathol 2010, 222:64-75.

21. Weigelt B, Geyer FC, Natrajan R, Lopez-Garcia MA, Ahmad AS, Savage K, Kreike B, Reis-Filho JS: The molecular underpinning of lobular histological growth pattern: a genome-wide transcriptomic analysis of invasive lobular carcinomas and grade- and molecular subtype-matched invasive ductal carcinomas of no special type. J Pathol 2010, 220:45-57.

22. Weigelt B, Reis-Filho JS: Histological and molecular types of breast cancer is there a unifying taxonomy? Nat Rev Clin Oncol 2009, 6:718-730.

23. van de Vijver MJ, He YD, van't Veer $L$, Dai H, Hart AA, Voskuil DW, Schreiber GJ, Peterse JL, Roberts C, Marton MJ, Parrish M, Atsma D, Witteveen A, Glas A, Delahaye L, van der Velde T, Bartelink H, Rodenhuis S, Rutgers ET, Friend SH, Bernards R: A gene-expression signature as a predictor of survival in breast cancer. N Engl J Med 2002, 347:1999-2009.

24. Peppercorn J, Perou CM, Carey LA: Molecular subtypes in breast cancer evaluation and management: divide and conquer. Cancer Invest 2008, 26:1-10.

25. Weigelt B, Mackay A, A'Hern R, Natrajan R, Tan DS, Dowsett M, Ashworth A, Reis-Filho JS: Breast cancer molecular profiling: a retrospective analysis of molecular subtype assignment using single sample predictors. Lancet Oncol 2010, 11:339-349.

26. Lusa L, McShane LM, Reid JF, De Cecco L, Ambrogi F, Biganzoli E, Gariboldi M, Pierotti MA: Challenges in projecting clustering results across gene expression-profiling datasets. J Natl Cancer Inst 2007, 99:1715-1723.

27. Chang HY, Nuyten DS, Sneddon JB, Hastie T, Tibshirani R, Sorlie T, Dai H, He YD, van't Veer LJ, Bartelink H, van de Rijn M, Brown PO, van de Vijver MJ: Robustness, scalability, and integration of a wound-response gene expression signature in predicting breast cancer survival. Proc Natl Acad Sci USA 2005, 102:3738-3743.

28. Fan C, Oh DS, Wessels L, Weigelt B, Nuyten DS, Nobel AB, van't Veer $\sqcup$, Perou $\mathrm{CM}$ : Concordance among gene-expression-based predictors for breast cancer. N Engl J Med 2006, 355:560-569.

29. Pusztai L, Mazouni C, Anderson K, Wu Y, Symmans WF: Molecular classification of breast cancer: limitations and potential. Oncologist 2006, 11:868-877.

30. de Ronde JJ, Hannemann J, Halfwerk H, Mulder L, Straver ME, Vrancken Peeters MJ, Wesseling J, van de Vijver M, Wessels LF, Rodenhuis S: Concordance of clinical and molecular breast cancer subtyping in the context of preoperative chemotherapy response. Breast Cancer Res Treat 2010, 119:119-126.
31. Wang Y, Klijn JG, Zhang Y, Sieuwerts AM, Look MP, Yang F, Talantov D, Timmermans M, Meijer-van Gelder ME, Yu J, Jatkoe T, Berns EM, Atkins D, Foekens JA: Gene-expression profiles to predict distant metastasis of lymph-node-negative primary breast cancer. Lancet 2005, 365:671-679.

32. Sotiriou C, Piccart MJ: Taking gene-expression profiling to the clinic: when will molecular signatures become relevant to patient care? Nat Rev Cancer 2007, 7:545-553.

33. Abdullah-Sayani A, Bueno-de-Mesquita JM, van de Vijver MJ: Technology Insight: tuning into the genetic orchestra using microarrays - limitations of DNA microarrays in clinical practice. Nat Clin Pract Oncol 2006, 3:501-516.

34. Ivshina AV, George J, Senko O, Mow B, Putti TC, Smeds J, Lindahl T, Pawitan Y, Hall P, Nordgren H, Wong JE, Liu ET, Bergh J, Kuznetsov VA, Miller LD: Genetic reclassification of histologic grade delineates new clinical subtypes of breast cancer. Cancer Res 2006, 66:10292-10301.

35. Sotiriou C, Wirapati P, Loi S, Harris A, Fox S, Smeds J, Nordgren H, Farmer P, Praz V, Haibe-Kains B, Desmedt C, Larsimont D, Cardoso F, Peterse H, Nuyten D, Buyse M, Van de Vijver MJ, Bergh J, Piccart M, Delorenzi M: Gene expression profiling in breast cancer: understanding the molecular basis of histologic grade to improve prognosis. J Natl Cancer Inst 2006, 98:262-272.

36. Ein-Dor L, Kela I, Getz G, Givol D, Domany E: Outcome signature genes in breast cancer: is there a unique set? Bioinformatics 2005, 21:171-178,

37. Michiels S, Koscielny S, Hill C: Interpretation of microarray data in cancer. $\mathrm{Br}$ J Cancer 2007, 96:1155-1158.

38. Desmedt C, Piette F, Loi S, Wang Y, Lallemand F, Haibe-Kains B, Viale G, Delorenzi M, Zhang Y, d'Assignies MS, Bergh J, Lidereau R, Ellis P, Harris AL, Klijn JG, Foekens JA, Cardoso F, Piccart MJ, Buyse M, Sotiriou C: Strong time dependence of the 76-gene prognostic signature for node-negative breast cancer patients in the TRANSBIG multicenter independent validation series. Clin Cancer Res 2007, 13:3207-3214.

39. Ioannidis JP: Microarrays and molecular research: noise discovery? Lancet 2005, 365:454-455

40. Reyal F, van Vliet MH, Armstrong NJ, Horlings HM, de Visser KE, Kok M, Teschendorff AE, Mook S, van 't Veer L, Caldas C, Salmon RJ, van de Vijver MJ, Wessels LF: A comprehensive analysis of prognostic signatures reveals the high predictive capacity of the proliferation, immune response and RNA splicing modules in breast cancer. Breast Cancer Res 2008, 10:R93.

41. Paik S, Shak S, Tang G, Kim C, Baker J, Cronin M, Baehner FL, Walker MG, Watson D, Park T, Hiller W, Fisher ER, Wickerham DL, Bryant J, Wolmark N: A multigene assay to predict recurrence of tamoxifen-treated, nodenegative breast cancer. N Engl J Med 2004, 351:2817-2826.

42. Paik S, Tang G, Shak S, Kim C, Baker J, Kim W, Cronin M, Baehner FL, Watson D, Bryant J, Costantino JP, Geyer CE, Jr., Wickerham DL, Wolmark N: Gene expression and benefit of chemotherapy in women with node-negative, estrogen receptor-positive breast cancer. J Clin Oncol 2006, 24:3726-3734.

43. Paik S: Development and clinical utility of a 21 -gene recurrence score prognostic assay in patients with early breast cancer treated with tamoxifen. Oncologist 2007, 12:631-635.

44. Kim C, Paik S: Gene-expression-based prognostic assays for breast cancer. Nat Rev Clin Oncol 2010, 7:340-347.

45. Dunkler D, Michiels S, Schemper M: Gene expression profiling: does it add predictive accuracy to clinical characteristics in cancer prognosis? Eur J Cancer 2007, 43:745-751.

46. Cuzick J, Dowsett M, Wale C, Salter J, Quinn E, Zabaglo L, Howell A, Buzdar A, Forbes JF: Prognostic Value of a Combined ER, PgR, Ki67, HER2 Immunohistochemical (IHC4) Score and Comparison with the GHI Recurrence Score - Results from TransATAC. Cancer Res 2009, 69:503S-503S (Abstract).

47. Reis-Filho JS: Next-generation sequencing. Breast Cancer Res 2009, 11 Suppl 3:S12

48. Aparicio SA, Huntsman DG: Does massively parallel DNA resequencing signify the end of histopathology as we know it? J Pathol 2010, 220:307-315.

\section{doi:10.1186/bcr2734}

Cite this article as: Weigelt B, Reis-Filho JS: Molecular profiling currently offers no more than tumour morphology and basic immunohistochemistry. Breast Cancer Research 2010, 12(Suppl 4):S5. 